\title{
Primitive Mammoth Hunters and the Earliest Breed of Dog
}

\author{
Petr N. Kolosov \\ Diamond and Precious Metal Geology Institute Siberian Branch, Russian Academy of Sciences, Yakutsk, Russia \\ Email: p kolosov@diamond.ysn.ru
}

Received 7 November 2013; revised 19 January 2014; accepted 7 February 2014

Copyright (C) 2014 by author and Scientific Research Publishing Inc.

This work is licensed under the Creative Commons Attribution International License (CC BY). http://creativecommons.org/licenses/by/4.0/

(c) (i) Open Access

\begin{abstract}
Primitive man have managed to survive in the rigorous climatic conditions of the arctic regions in northeast Asia owing to the hunting for mammoth, bison, wooly rhinoceros and other Pleistocene mammals with the assistance of the laika, a domesticated wolf. This is how the colonization of the Arctic began. The domestic dog appeared in this region about 25 - 30 thousand years ago as a result of the severe climatic conditions in which both hunting tribes and the ancestors of the domestic dog had to live. A wolf is a predator, an able hunter. Therefore, most likely wolves were originally trained to hunt with humans - the leaders of the hunting pack. Thus, in northeast Asia, there was a direct relationship between man's colonization of the Arctic, the appearance of the hunting dog, and a decrease in the number of mammoth, bison, and other large animals in the region, as a result of hunting when whole herds were killed.
\end{abstract}

\section{Keywords}

Asia; Arctic; Paleolithic; Mammoth; Primitive Hunter; Wolf; Domestication; Dog

\section{Introduction}

Nowadays, the Arctic is of intense interest to the world. It is connected with the continental shelf's energy resources and the actual problems of Earth's climate, abilities of the Northern Maritime, fishing and tourism.

The question of how man managed to survive and earn his living in the severe climatic conditions of the arctic regions in northeast Asia (later on moved to America) in the Late Paleolithic (30 ka) is very interesting. Another intriguing question is how the domestication of the wolf in the given areas came about. It is a problematical interdisciplinary subject, directly connected with the history of mankind and the beginning of human survival in the Arctic.

About 30 thousand years ago, hunting tribes reached arctic latitudes in Siberia, northeast Asia. This is evi- 
denced by a Paleolithic site found at the mouth of the Yana river (at $30 \mathrm{ka}$ ) falling into the Laptev Sea [1] (Figure 1). According to Schirrmeisner et al. [2], at 48 - 33.5 ka the climate in the Lena river delta was close to that existing now.

Primitive man hunted for mammoth, bison, wooly rhinoceros, musk-ox, wild horse and other animals. He could see that along with him wolves preyed on these large animals too, migrating toward northeast Asia. These two hunters, man and wolf, constantly ran into each other, particularly beside the bodies of dead mammoths.

Ancient hunters could see that the wolf is an intelligent, cautious and observant animal; it has excellent hearing and sight, and a fantastic sense of smell. A wolf can lie in ambush and wait for a convenient moment to attack prey. It can run fast (up to $65 \mathrm{~km} / \mathrm{h}$ ), is strong, and knows well that hunting in packs for large animals yields better results.

Of all the animals, the dog is man's best friend and helper. However, the questions concerned with the origin of the domestic dog are debatable and as yet poorly studied. No wonder they are ignored by many authors [3].

Genetic scientists from the USA, Sweden, and Australia have concluded that the domestic dog first appeared in northeast Asia. This conclusion was based on the fact that the gene composition of dogs from this region is highly variable, which is indicative of their long evolution [3]. The finding of two dog skulls on the Rassokha River, a left tributary of Alazeya falling into the East Siberian Sea, confirm this conclusion (Figure 1). The skulls were removed from the Edoma Formation aged at 25 - 35 ka [4].

\section{With Wolf to Domestic Dog}

According to molecular genetic data, it's clearly defined that, all dogs are descendants of wolves. Apparently the domestication of the wolf went on in several populations [5] at different times in different regions of the world [6] [7]. We won't discuss where and when the domestic dog first appeared and became important for man [7][9]. We'll focus on an interesting little-studied theme-the reasons and methods of the domestication of the wolf. There could have been several reasons and ways. Man needed dogs as: helpers for hunting [8]-[12]; a food source [13]; a protector of the dead [9]; a guard [14] [15]; a friend [9]; a draught dog, a deer flushing dog etc.

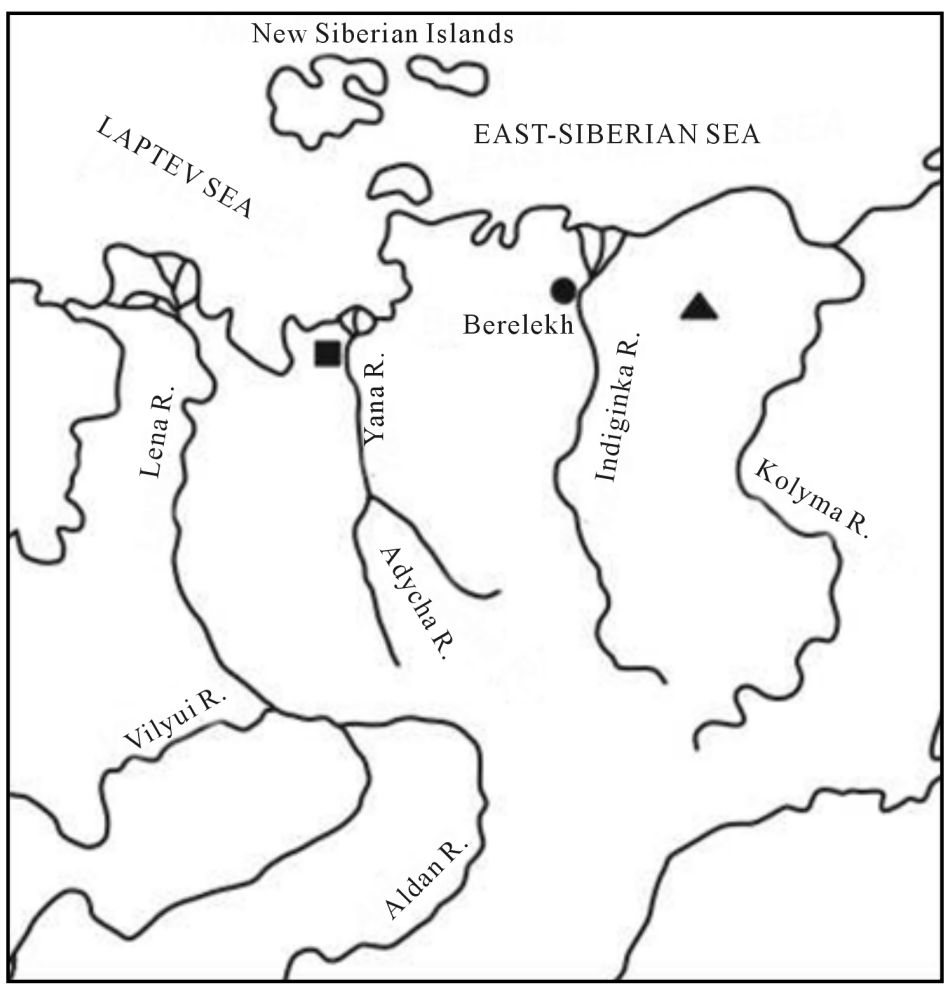

Figure 1. East siberia. Locations: --Man settlement in Yana river mouth; $\mathbf{\Delta}$ - site of discovery of dog skulls along Rassokha river; Berelekh mammoth "cemetery". 
Wolf breeding in China for food apparently was like keeping rabbits and foxes in cages, i.e. not domestication. A wolf is a predator, an able hunter. Therefore most likely wolves were originally trained to hunt with humans the leaders of the hunting pack. Only after domestication did the dog become a guard, a friend, a draught dog etc.

For many thousands of years, hunting tribes from the North East-Asia could take still blind wolf-cubs from their dens (examples of this are seen even nowadays) to breed them. Growing together with the hunters' children, the wolves could retain the smell of man in their memory, imitate man's voice, first making short sharp sounds and centuries later, learning to bark. The ability to bark is a great advantage of dogs over wolves, which can only howl.

Grown in captivity and then set free (due to the problems of feeding and keeping), the half-domestic wolves could hardly survive in the rigorous conditions of the Arctic. They couldn't rival wolves living in the wild, which were taught to obtain food by their mothers. These half-domestic wolves couldn't make sense of the sounds produced by wild wolves. Therefore in the cold and barren Arctic they had to adapt themselves to man (hunger made them remember that humans give food), get accustomed to his smell. Little by little they were winning man's confidence. Thousands of years later, these wolves could give rise to a new species Canis familiaris (domestic dog) of the genus Canis (dog, wolf).

In their young age (“a critical period”), domestic animals gain early experience of contact with people, which is inherited by future generations [16]. This was the case with the domesticated wolf.

When selecting a domestic dog to help in hunting, primitive man took into account its morpho-functional characteristics [17]. This sped up the processes of morpho-physiological differentiation and specialization of individual breeds [18] (p. 16). As a result, there is a great variety of domestic dogs nowadays. Repeated interbreeding of domestic dogs with wolves and wild dogs as well as intraspecific hybridization could have played an important role in this.

In his wonderful book “Origin of species by means of natural selection”, Charles Darwin wrote: “....habit, with some degree of selection, has probably concurred in civilising by inheritance our dogs” [19] (p. 215). High rate of appearance (presumably less than thousand years) of huge amount (over 200) of breeds of dogs shows their remarkable variability and efficiency of artificial selecton [20]. The domestication process was facilitated by hunting with humans, making use of one of the wolf's genetic traits - predisposition to hunting. Wolf is a clever beast that is why it could quickly learn the instructions of hunter (group leader) while hunting - driving mammoths and other representatives of mammoth fauna into shore cliffs or fragile ice.

The former implies that vast Yakutia located in the extreme north, Eastern Asia may be referred to as the center or one of the centers of the domestic dog’s origin. It appears that the strong northern hunting dog ("laika") with three-cusped carnassial teeth [21] and sharp-tipped erect ears, as with wolves, is the earliest breed of domestic dog.

Thus, in severe climatic conditions the ancestors of the domestic dog could have made friends with humans hunting for mammoths and other animals. Severe climatic conditions of the North East-Asia, where one can make living mainly only by hunting, forced wolf to adapt to live with primitive hunter. On cold expanses, all covered with snow (sometimes deep), of the Arctic, hunger forced wolf to shorten the distance of avoiding. It was caused by numerous attempts of hunters to domesticate wolf-cubs, i.e. beginnings of selection. From the available scientific data it follows that in Yakutia with the most severe climate in the whole of eastern Asia, where humans could not survive just by gathering, about 30 thousand years ago the hunting tribes and wild beasts (half-domesticated wolves) needed each other's help for survival more badly than people and animals on the continents with better living conditions. Primitive man inhabiting the territory of present-day Yakutia hunted for mammoths for about 20 - 25 thousand years. This was a long enough period for him to breed a helper for hunting. He apparently was first on Earth to domesticate a wolf. Only the hunting laika could have descended from the wolf and survived in the adverse climatic conditions about 30 thousand years ago thanks to its stamina and great skill in hunting. It retained many qualities of a wolf. The author has observed more than once in arctic Yakutia how wolves hunted in packs for reindeer and laikas for hares and squirrels. It appears that it was precisely such a helper that primitive man needed, one which could make a team with him. Dogs helped man to stalk mammoths, bison and other animals, they distracted their attention from the human hunters, they could surround a prey animal or even whole mammoth herds much quicker than humans could, and were indispensable in bringing animals to shore cliffs (Figure 2) or ambushes (in the present day one may see how laikas in the tundra drive domestic reindeer to herdsmen; a deer herd of $3-4$ thousand heads has been driven to a new area 


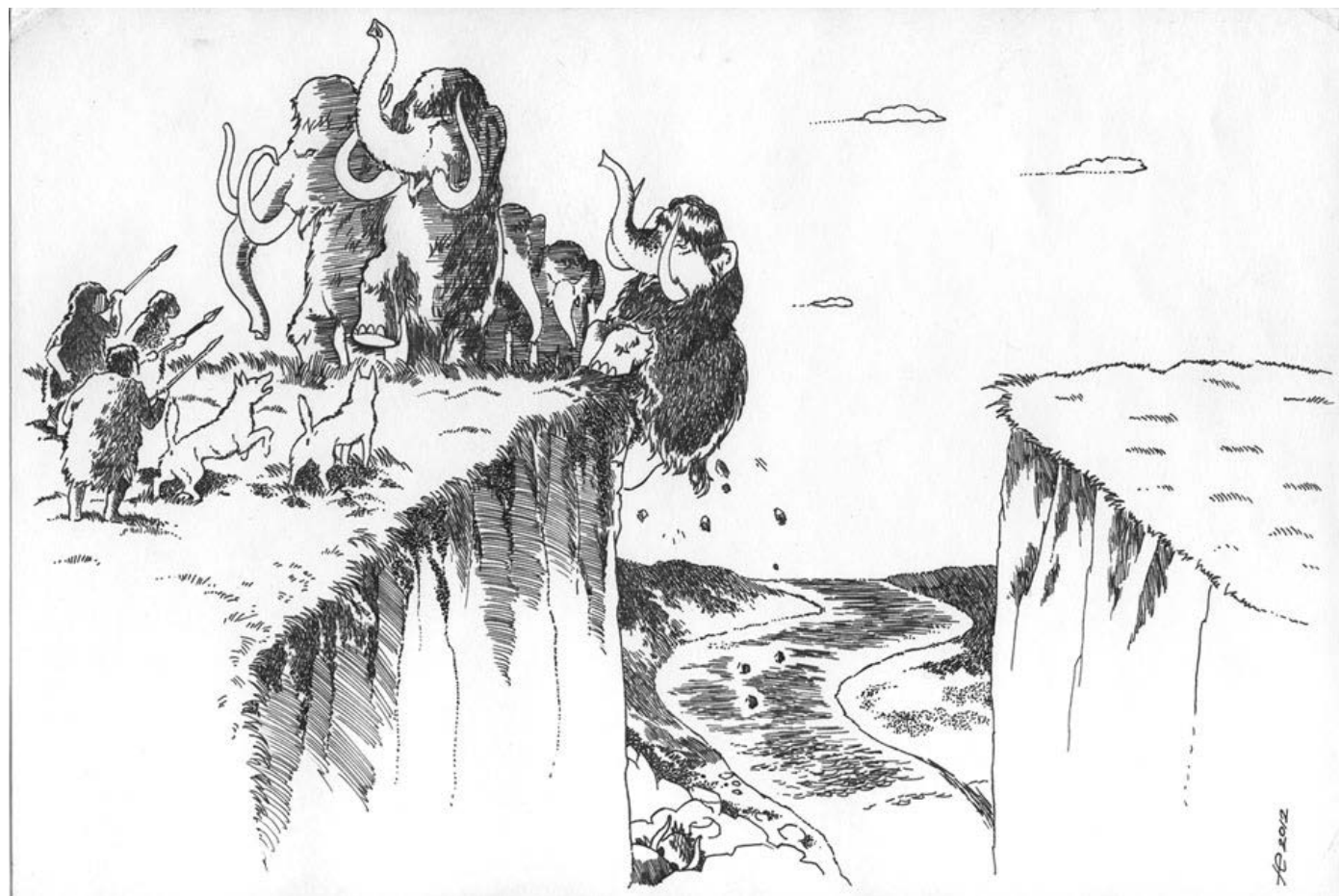

Figure 2. Scene of prehistorical people mammoth hunting by driving them with dogs (artist E. Y. Nesterova).

by only several herdsmen and their trained laikas).

A hunter bred a dog for hunting by selection, taking into account the above-mentioned qualities. Since hunting was the earliest occupation of man in the extreme north this proves that the laika is the oldest domestic dog on Earth.

\section{Hunting Mammoths}

Primitive man could have survived in the severe climate by killing large animals, mammoths among them, to obtain food. About 40 thousand heads of mammoths lived annually in northeast Asia at the time of the mammoths' prime (30 - 15 thousand years ago) [22]. It is reasonable to suppose that hunting for such giants was difficult without special tools. First people of the North East-Asia were armed with stone tools and flint-tipped spears. Mammoths have long hair with dense undercoat, thick skin $(1.0-1.5 \mathrm{~cm})$. That is why hunting mammoths by bringing them to shore cliffs or fragile ice was more effective than hunting with mentioned tools. Hunting by bringing animals to shore cliffs etc. has been known for a long time. What was unclear was how humans managed to drive mammoths anywhere. Judging by modern elephants, in case of need mammoths could run faster than people over short distances, and could scatter to escape from danger (steep cliffs, ice, ambushes). The participation of dogs made hunting successful. But this led to a significant decrease in the number of mammoths and bison (there was a large quantity of both). It could be assumed that, during the existence of mammoths there were not a large number of humans, and so humans could not have caused the disappearance of these animals. However, from the foregoing it follows that in order to have a piece of meat for a meal primitive hunters killed whole mammoth herds by driving them to shore cliffs or to the ice covering deep rivers, lakes and former river-beds with the help of dogs. Since meat in the skin got rotten very quickly, the hunters had to obtain fresh meat every week by killing mammoths again and again. This shows that man has played a significant role in the reduction of the mammoth population, and can explain the presence of "bone yards" scattered along rivers in the arctic regions of northeast Asia. In Africa, primitive hunters of large animals didn't cause significant reduction of their diversity [23]. Except meat, they used edible plants. In contrast, our ancestors in the Northeastern Asia had to be content mostly with the meat of animals, because they had nothing to gather (except berries during very short summer).

The Berelekh mammoth cemetery extends for $200 \mathrm{~m}$ along the river under the same name, a left tributary of 
the Indigirka falling into the East Siberian Sea. Before erosion, it occurred at the cultural layer level at a depth of 2.55 m. In 1970, a group of specialists from the Zoological Institute of the Russian Academy of Sciences (St. Petersburg) headed by Prof. Vereshchagin, an expert on mammoths, collected there over 10 thousand bones belonging to no less than 120 mammoths (Figures 1, 3). According to Vereshchagin [24], 1600 - 1800 mammoths died at this site within a short period. Their bones are buried under the ground of the Berelekh river. Judging from the bones, mainly cows, young animals and calves died. Hunters knew well that the meat of big bulls is very tough, hard for chewing. Evidently there was much feed in this place and mammoth herds often came and fell prey. Wolf bones have also been found there. Some of the mammoth bones (radiocarbon dating yielded the ages of 10.0 - 12.0 to $13.7 \mathrm{ka}$ ) show signs of having been gnawed by wolves, wolverines and, likely, dogs. There is a primitive human campsite near this place $\left(71^{\circ} \mathrm{N}\right)$, where a piece of tusk with the figure of a mammoth inscribed on it has been discovered. Apparently the hind leg of a mammoth found there $(175 \mathrm{~cm}$ long, weight 170 kg) (Figure 4) was part of the humans' supply. It has been excellently preserved in the frozen earth. The leg was covered with hide and long red hair.

Driven hunting for large animals was used later on during mass culling of wild reindeers. It's defined by archeologists based on materials of Paleolithic cultural monuments in Okhotsk-Kolyma highland at northeastern Asia [25]. Now we know how the domestication of wolves happened in eastern Asia, where dogs became domesticated earlier than anywhere else according to the referenced (and other) scientists [26] genetic research.

Thus, in northeast Asia there was a direct relationship between the hunting of representatives of the mammoth fauna by ancient humans, the appearance of the hunting dog, and a decrease in the number of mammoths, bison and other large animals in the region.

Nomadic hunters of mammoth fauna, settled North-East Asia 30 thousand years ago, after about 10, or a few thousand years, they have started to enter America by land bridge between Chukotka and Alaska. Later on, they settled this continent [27]. According to genetic data, Asian origin of Native Americans is without any doubt [23] [28].

\section{Conclusions}

Primitive men have managed to survive in the rigorous climatic conditions of the arctic regions in northeast Asia owing to the hunting of mammoths, bison, wooly rhinoceros and other Pleistocene mammals with the as-

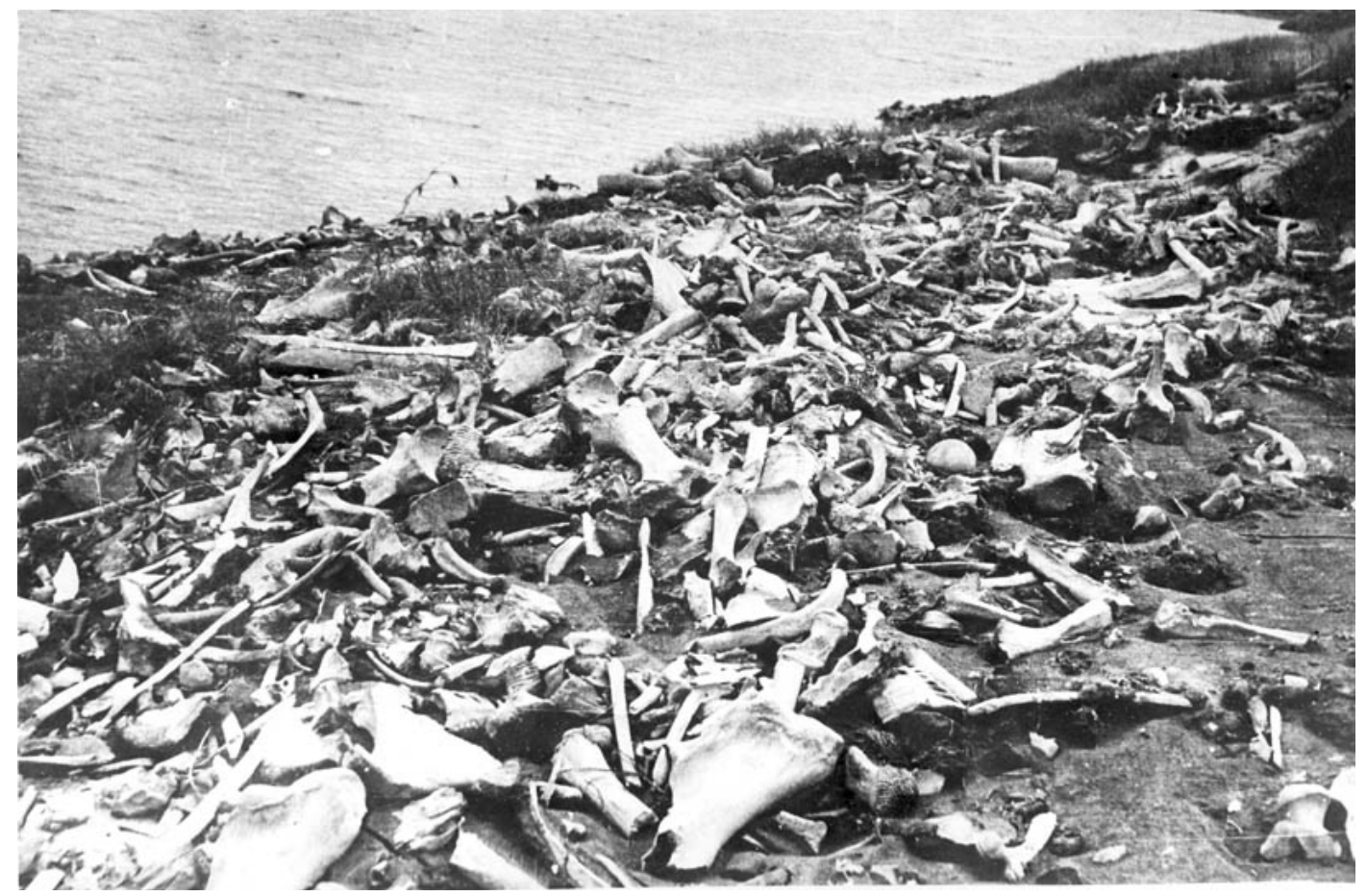

Figure 3. The berelekh mammoth “cemetery” in Indigirka river basin. 


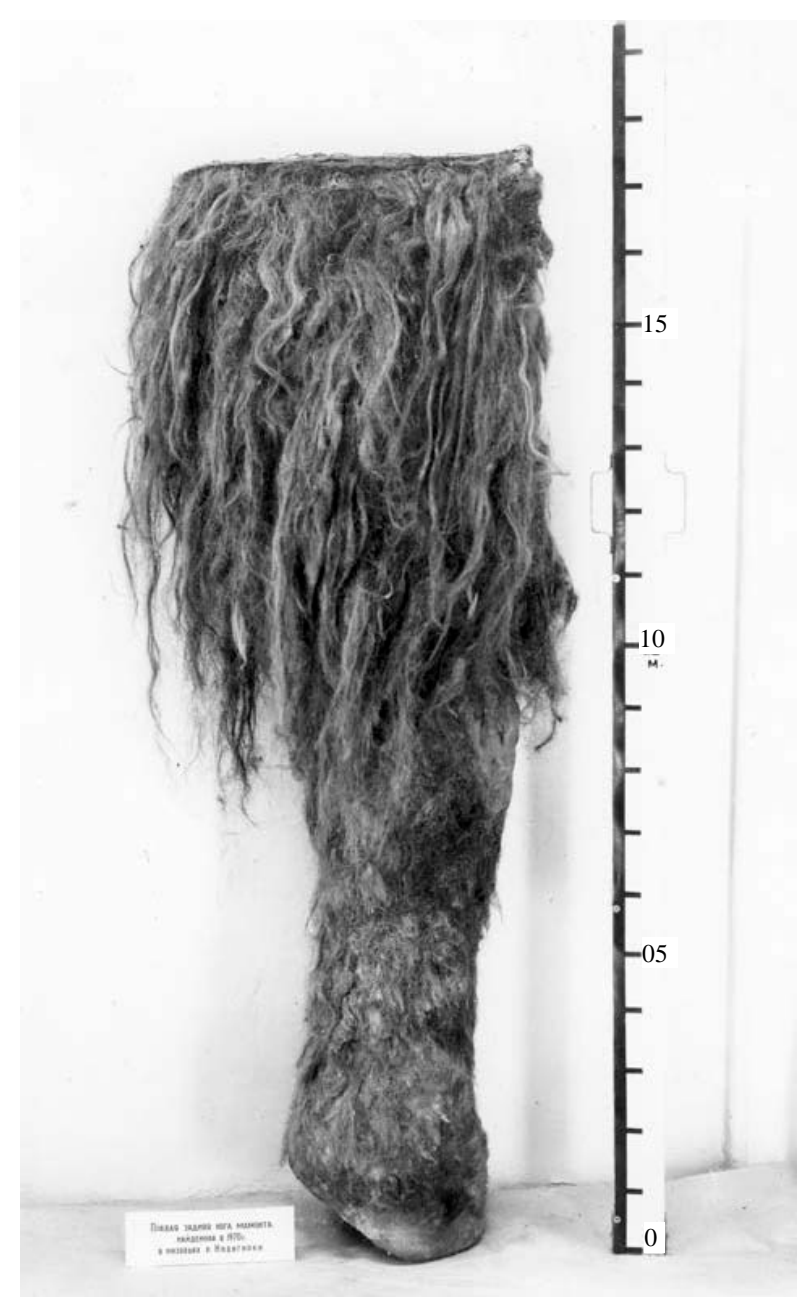

Figure 4. Hind leg of a mammoth: length $175 \mathrm{~cm}$, weight $170 \mathrm{~kg}$. Exhibit No. 6830 from the collection of the Geological Museum, IGABM SB RAS (Yakutsk).

sistance of the laika, a domesticated wolf. In northeastern Asia there was no sheet glaciation for the last 60 thousand years.

The author believes that, the above-mentioned is the most logic explanation of wolf domestication in the North East-Asia and early human settlement in Arctic. This is how the colonization of the Arctic began. This colonization is one of the great achievements of mankind within the last 30 - 35 thousand years.

\section{References}

[1] Tikhonov, A. and Burlakov, Yu. (2008) Reasons for the Death of Northern Giants. Science in Russia, 3, 48-53. (in Russian)

[2] L. Schirrmeisner et al. (2002) Paleoenvironmental and Paleoclimatic Records from Permafrost Deposits in the Arctic Region of Northern Siberia. Quaternary International, 89, 97-118. http://dx.doi.org/10.1016/S1040-6182(01)00083-0

[3] Korabel'nikov, V.A., Korabel'nikova, T.V. and Korabel'nikov, A.V. (1993) Legends and Facts about Dogs: First Tamed by Man. Prosveshcheniye, Moscow, 225. (in Russian)

[4] Guriev, K.N., Lazarev, P.A. and Kolosov, P.N. (2001) Giants of the Glacial Period. Tsumori Press, Yakutsk, 144. (in Russian)

[5] Wayne, K.K. and Ostrander, E.A. (1999) Origin, Genetic Diversity, and Genome Structure of the Domentic Dog. BioEssays, 21, 247-257. http://dx.doi.org/10.1002/(SICI)1521-1878(199903)21:3<247::AID-BIES9>3.0.CO;2-Z 
[6] Trut, L.N. (2007) Domestication of Animals in Historical Process and Experiment. Vestnik VOGiS, 11, 273-289. (in Russian)

[7] Ovodov, N.D., et al. (2011) A 33,000-Year-Old Incipient Dog from the Altai Mountains of Siberia: Evidence of the Earliest Domestication Disrupted by the Last Glacial Maximum. Public Library of Science ONE, 6, 1-7.

[8] V. Germonpre et al. (2009) Fossil Dogs and Wolves from Palaeolithic Sites in Belgium, the Ukraine and Russia: Osteometry, Ancient DNA and Stable Isotopes. Journal of Archaeological Science, 36, 473-490. http://dx.doi.org/10.1016/j.jas.2008.09.033

[9] http://dog-dogi.narod.ru/

[10] Kolosov, P.N. (2009) Domestication of Wolf or Wild Dog. Science and Education, 2, 86-89. (in Russian)

[11] http://www.ohotayakutia.ru/content/

[12] Dolnik, V.R. (2011) Naughty Chilled of Biosphere. Conversations about Human Behavior in the Company of Birds, Animals and Children. Petroglif, SPb., MZNMO, Moscow, 852. (in Russian)

[13] http://www.membrana.ru/particle/14103

[14] www.allvet.ru/guide/dog.php

[15] J-F. Pang et al. (2009) mtDNA Data Indicate a Single Origin for Dogs South of Yangtze River, Less Than 16,300 Years Ago, from Numerous Wolves. Molecular Biology and Evolution, 26, 2849-2864. http://dx.doi.org/10.1093/molbev/msp195

[16] Arshavskiy, I.A. (1972) Physiological Mechanisms for the Formation of Phenotype in Ontogeny and the Problem of Domestication of Mammals: Problems of Domestication of Animals and Plants. Nauka, Moscow, 27-32. (in Russian)

[17] Novikov, E.A. (1971) Regularities in the Development of Agricultural Animals. Kolos, Moscow, 224. (in Russian)

[18] Schwartz, S.S. (1972) Domestication and Evolution: Problems of Domestication of Animals and Plants. Nauka, Moscow, 13-17. (in Russian)

[19] Darwin, Ch. (2001) Origin of Species by Means of Natural Selection. Translated into Russian. 2nd edition, Nauka, St. Petersburg, 568. (in Russian)

[20] Dawkins, R. (2012) The Greatest Show on Earth: The Evidence for Evolution. Translation from English. Astrel: CORPUS, 496.

[21] Samar, A.P. (1997) Dog Breeding by Nanaians in the 19th-early 20th centuries: Ethnic Groups and Environment. Dal'nauka, Vladivostok, 67-80. (in Russian)

[22] Vereshchagin, N.K. (1979) Why Did the Mammoths Become Extinct. Nauka, Moscow, 196. (in Russian)

[23] Markov, A.V. (2011) Human Evolution. The book 1: Monkey, Bones and Genes. AST: CORPUS, Moscow, 464.

[24] Vereshchagin, N.K. (1981) Paleontologist’s notes. In the Footsteps of Ancestors. Nauka, Moscow, 166. (in Russian)

[25] Slobodin, S.B. (2011) Archeological and Peloecological Aspects of Life Support of Ancient Civilizations from Okhotsk-Kolyma Highland in Northeastern Asia. Ecology of Ancient and Traditional Societies: Collection of Conference Reports, Izdatelstvo IPOS SO RAN, Tyumen, 142-145. (in Russian)

[26] Salvolainen, P., Zhang, Y.-P., Luo, J., Lunderberg, J. and Leitner, T. (2002) Genetic Evidence for a East Asian Origin of Domestic Dogs. Science, 298, 1610-1613. http://dx.doi.org/10.1126/science.1073906

[27] Goebel, T., Waters, M.R. and O’Rourke, D.H. (2008) The Late Pleistocene Dispersal of Modern Humans in the Americas. Science, 319, 1497-1502. http://dx.doi.org/10.1126/science.1153569

[28] Zakharov, A. (2003) Central-Asian Origin of the Ancestors of the First Americans. First Americans, 11, 139-144. 